\title{
The Asian Region and the International Criminal Court
}

\author{
Hitomi Takemura
}

\section{Introduction}

As of May 2017, the International Criminal Court (hereinafter the ICC or Court) had 124 States Parties. Among them, 19 states and regions belong to the Asia-Pacific region, based on the United Nations Regional Group. ${ }^{1}$ Although the Asia-Pacific region is home to half of the global population, the people of the region, especially those living in Southeast Asian states, are apparently underrepresented at the ICC. Only two of the ten Member States of the Association of Southeast Asian Nations (ASEAN) - that is, Cambodia and the Philippineshave ratified the Rome Statute. Although, with the exception of Jordan, the Arab states' lack of participation in the ICC is also conspicuous, the Asia-Pacific region's comparatively lower acceptance rate undoubtedly undermines the universality of the Rome Statute and the ICC system. Even worse, Philippines' President Rodrigo Duterte said on 17 November 2016 that he might follow the example of Russia and have the Philippines withdraw from the ICC. ${ }^{2}$ The future prospects of the Asian region's involvement with the ICC thus currently appear to hang in the balance.

First, the present article explores the reluctance by Asian states to accept the Rome Statute and the ICC. Second, it explores the current relationship between the Asian region and the ICC, especially from the perspective of preliminary investigation activities by the ICC in the Asian region. Despite Asian states' hesitations

\footnotetext{
${ }^{1}$ Those states and regions are Fiji, Tajikistan, Marshall Islands, Nauru, Cyprus, Cambodia, Jordan, Mongolia, Timor-Leste, Samoa, Republic of Korea, Afghanistan, Japan, Cook Islands, Bangladesh, Philippines, Maldives, Vanuatu, and Palestine.

${ }^{2}$ See e.g., Forster (2016).

H. Takemura $(\bowtie)$

Graduate School of Law, Hitotsubashi University, Tokyo, Japan

e-mail: hitomi.takemura@r.hit-u.ac.jp; takemurahitomi@hotmail.com

(C) The Author(s) 2018

Y. Nakanishi (ed.), Contemporary Issues in Human Rights Law, https://doi.org/10.1007/978-981-10-6129-5_6
} 
about the ICC, the investigative screws may be tightening on the Asian region, as the Office of the Prosecutor (OTP) is conducting preliminary examinations in several Asian states. Last, this article forecasts the future prospects for the Asian region and the ICC by analysing the on-going preliminary examinations of an Asian incident.

\section{The Rationale Behind Asian Reluctance: Various Policy Considerations and So-called Asian Values}

The rationales behind the hesitancy of the Asian region to join the Rome Statute should be clarified. Are these rationales legal or political? Seemingly, the rationales provided by governments are legal ones. Especially the Chinese government's argument against the ICC appears to be very legal and partially reflects its own status as one of the permanent five Member States of the Security Council. The Chinese government provides the following five reasons why it has not signed the Rome Statute $^{3}$ : First, the jurisdiction of the ICC is not based on the principle of voluntary acceptance; the Rome Statute imposes obligations on non-States Parties without their consent, which violates the principle of state sovereignty and the Vienna Convention on the Law of Treaties. The Chinese government also regards it as problematic that the complementarity principle gives the ICC the power to decide whether a state is able or willing to conduct proper trials of its own nationals. Second, the Chinese government calls into question the scope of the definition of war crimes. For China, it is problematic that war crimes committed in internal armed conflicts fall within the jurisdiction of the ICC. Moreover, the Chinese government finds it questionable that the definition of "war crimes" goes beyond those accepted under customary international law and in Additional Protocol 2 to the Geneva Conventions. Third, the Rome Statute's definition of "crimes against humanity" does not require that the state in which they are committed be "at war" while, from the standpoint of China, the existing customary international law norm does. From the Chinese perspective, the list of acts prohibited as crimes against humanity in the Rome Statute belong to the area of interest of international human rights law rather than international humanitarian law. Fourth, the Chinese government is concerned that the inclusion of the crime of aggression within the jurisdiction of the ICC invokes the power of the UN Security Council. Fifth, China argues that the proprio motu power, the power of the Prosecutor under Article 15 of the Rome Statute to choose a situation at her own initiative rather than receiving a referral from either a State Party or the Security Council permits the Prosecutor to act in a political manner rather than in a manner that is independent and fair.

\footnotetext{
${ }^{3}$ See Jianping and Wang (2005, pp. 611-612).
} 
While the Chinese government's explanation - which is endorsed by some Southeast Asian governments-seems legal and political, ${ }^{4}$ cultural explanations have also been offered as possible reasons for why many Asian countries have not acceded to the Rome Statute. Motoo Noguchi, who is currently chair of the Board of the Directors of the Trust Fund for Victims of the ICC and a former Supreme Court Chamber Judge of the Extraordinary Chambers in the Courts of Cambodia, has identified four common features of Asian society and culture that might be hindrances to Asian states joining the ICC. First, Noguchi points out that law has not traditionally been the primary guiding principle of Asian society, and to some extent, it is still not in many parts of Asia. ${ }^{5}$ Whereas in other parts of the world the courthouse, like the church, has been an integral part of the community, the law and lawyers play a lesser role in Asia, especially because of Asian people's preference for unofficial dispute settlement outside of courts. ${ }^{6}$ Second, the criminal justice systems of many Asian countries have fundamental problems, so they are not supported by a majority of nationals. ${ }^{7}$ A culture of corruption flourishes in such countries, and they face limits on or a lack of judicial independence. ${ }^{8}$ Third, many people of the Asian region consider matters relating to criminal justice to be a sovereign matter that is essentially within the domestic jurisdiction and immune to external intervention. ${ }^{9}$ Fourth, the immense diversity of the region prevents the Asian people from opening a discussion on criminal justice in international or regional forums. ${ }^{10}$

Setting aside the stringency and reasonableness of the above cultural explanations about a region with diverse cultures, the third concern appears to misconstrue the ICC's principle of complementarity, according to which the Court may only exercise its jurisdiction when national jurisdictions are themselves unable or unwilling to investigate or prosecute (Article 17(1)(a) of the Rome Statute). Nevertheless, it is understandable that states that are unable, if not unwilling, to investigate and/or prosecute serious crimes of international concern would be apprehensive about joining the ICC. There is a need for Asian countries to have confidence in their own criminal justice systems. Then, they would not fear the ICC's jurisdictional reach into their sovereign matters.

After all, the ICC's complementary jurisdiction requires international society to support the development of the legal and functional capacity of developing countries. Otherwise, theoretically developing countries having problems with the

\footnotetext{
${ }^{4}$ The spokesman for the then Philippines president reportedly said in September 2002 that endorsing the Rome Statute would open the floodgates to further malicious allegations, while the security forces of the Philippines already had to deal with internal rebellions. Toon (2004, pp. 219220).

${ }^{5}$ Noguchi (2006, p. 587).

${ }^{6}$ Ibid pp. 587-588.

${ }^{7}$ Ibid p. 588.

${ }^{8}$ Ibid.

${ }^{9}$ Ibid p. 589.

${ }^{10}$ Ibid p. 590.
} 
functioning of their criminal justice systems will always be "unable genuinely to carry out the investigation or prosecution" according to the admissibility criteria for situations and cases before the ICC under Article 17 of the Rome Statute. The legal culture of the Asian region can essentially be characterised as formalised justice processes detached from indigenous or embedded methods for resolving conflicts. Non-Western legal forms existing the Asian region are also considered, in part, to prevent Asian states from ratifying the Rome Statute. ${ }^{11}$ While the principle of complementarity has precipitated ICC membership among those African states hoping for the ICC to shoulder their burden to investigate and prosecute domestic crimes, it has hindered membership among Asian states fearing the Court's interference in their domestic affairs. In this sense, the principle of complementarity may be a double-edged sword.

\section{Future Prospects of the Asian Region and the International Criminal Court}

\subsection{Future of Non-state Parties of the Rome Statute}

Is there any hope that additional states from the Asian region will accede to the Rome Statute? The European commitment to the Asian region in this regard is remarkable. The European Union has strongly promoted the ICC since the Court's establishment. ${ }^{12}$ All EU Member States signed and ratified the Rome Statute within four years, ${ }^{13}$ and now all 28 EU Member States are ICC Member States. In June 2007, the European Council adopted the EU Strategy for Central Asia. Subsequently, in 2009, the European Union stated:

In promoting the consolidation of peace and international justice, the European Union and its Member States are determined to share with the Central Asia States their experience in the adoption of the necessary legal adjustment required to accede to the Rome Statute of the International Criminal Court, and in combating international crime in accordance with international law. ${ }^{14}$

Prior to the Strategy, the Asia-Europe Meeting (ASEM), an informal meeting between European Union Member States and 21 Asian states including the ASEAN Secretariat, had been a place for dialogue on the topic of the ICC. For example, the fifth Asia-Europe Meeting (ASEM 5) was held in Hanoi, and the leaders of the EU

\footnotetext{
${ }^{11}$ Findlay (2014, p. 87). Jo and Simmons (2016, pp. 452-453).

${ }^{12}$ De Búrca (2013, p. 55). The European Union concluded its first agreement with another international organization: Agreement between the EU and the ICC of 6 December 2005 on Assistance and Cooperation.

${ }^{13}$ Groenleer (2015, p. 928).

${ }^{14}$ General Secretariat of the European Council (2009, pp. 16-17).
} 
and Asian states agreed to continue dialogue on the ICC. ${ }^{15}$ Furthermore, at ASEM 6 in 2006, the leaders "referred to the need to ensure that there is no impunity for the most serious international crimes and discussed in this context the role of the International Criminal Court (ICC)."16 Since then, the focus of ASEM has arguably shifted from the ICC to combating piracy and cybercrime.

Nonetheless, since 2002, the European Union itself keeps encouraging the ratification and implementation of the Rome Statute in areas where the ICC is underrepresented. The EU's attempts reportedly contributed to increasing the number of States Parties to include Asian states such as Japan and Maldives. ${ }^{17}$ Hopefully, such encouragement and extrinsic motivation will continue to cultivate new ICC members from South East Asia.

Apart from South East Asian prospects for ICC participation, some have an encouraging perspective on the future relationship between China and the ICC. For instance, Hafetz writes: "As China becomes more proactive in global affairs, particularly through increased multilateral humanitarian interventions, it will likely become more engaged with the ICC and supportive of its activities."18

\subsection{Overview of the Current Relationships Between the Asian Region and the International Criminal Court}

\subsubsection{Present Circumstances}

Although not many Asian states have made much headway toward ICC participation, four situations geographically belonging to the Asian region have been or are the subject of preliminary examinations by the ICC OTP, and they fall within different phases of pre-investigation in accordance with the OTP's classifications.

The OTP has publicly proclaimed that "the Office has established a filtering process comprising four phases." ${ }^{\prime 19}$ Phase 1 consists of an initial assessment of all information on alleged crimes received under Rome Statute Article 15. Phase 2, which represents the formal commencement of a preliminary examination, is an investigation into whether preconditions to the exercise of jurisdiction under Article 12 are satisfied and whether a reasonable basis exists to believe that the alleged crimes fall within the subject-matter jurisdiction of the Court. Phase 3 focuses on

\footnotetext{
${ }^{15}$ ASEM 5 (October 2005), Chairman's Statement, Hanoi, para. 1.4.

${ }^{16}$ ASEM 6 (10-11 September 2006), Chairman's Statement of the Sixth Asia-Europe Meeting, Helsinki, p. 4, para. 12.

${ }^{17}$ European Union (7 July 2014), the European Union's Reply to the Information Request in paragraph 6, sub-paragraph h) of the Plan of Action for Achieving Universality and Full Implementation of the Rome Statute, p. 4, para. 2.1.

${ }^{18}$ Hafetz (2014, p. 54).

${ }^{19}$ Office of the Prosecutor (2016, p. 4), para. 15.
} 
the admissibility of potential cases with regard to their gravity and the principle of complementarity, while continuing to collect information on alleged new or on-going crimes. Phase 4 examines interests of justice considerations to formulate a final recommendation to the Prosecutor on whether a reasonable basis exists to initiate an investigation.

The four situations relating to the Asian region are (i) the situation of the Republic of Korea (phase 1), (ii) the situation of Ukraine (phase 2), (iii) the situation of Afghanistan (phase 3) and (iv) registered vessels of Comoros, Greece, and Cambodia (situation under reconsideration).

\subsubsection{Situation of the Republic of Korea}

First, on 6 December 2010, the ICC OTP announced that it had opened a preliminary examination to evaluate whether two incidents that occurred in 2010 in the Yellow Sea, namely the sinking of a South Korean warship, the Cheonan, on 26 March 2010 and the shelling of South Korea's Yeonpyeong Island on 23 November 2010 , could amount to war crimes under the jurisdiction of the Court. ${ }^{20}$ The OTP found that the contextual requirement of the existence of an international armed conflict was met in this situation by the alleged launching of a torpedo at the Cheonan and the launching of artillery shells onto Yeonpyeong. ${ }^{21}$ However, the Prosecutor concluded that, based on a thorough legal and factual analysis of the information available in June 2014, the statutory requirements for seeking authorization to initiate an investigation of the situation in the Republic of Korea had not yet been satisfied. ${ }^{22}$

As to sinking of the Cheonan, since the Cheonan was a naval vessel and all those on board who drowned - 46 sailors from the Republic of Korea-were military personnel, the OTP thought it was not a war crime to attack military objectives including naval ships or to kill enemy military personnel including sailors on a naval ship. ${ }^{23}$

The OTP subsequently determined that the prohibition on the conclusion of an agreement suspending combat with the intention of attacking by surprise an adversary relying on it is not listed as a war crime in the Rome Statute and customary law is unclear. ${ }^{24}$ Moreover, the OTP said that it would need to be shown that the Democratic People's Republic of Korea (DPRK) entered into the armistice agreement of 1953 with the specific intent to conduct surprise attacks such as the alleged 2010 attack on the Cheonan. ${ }^{25}$

\footnotetext{
${ }^{20}$ Office of the Prosecutor (2014a), p. 3, para. 2.

${ }^{21}$ Ibid p. 5, para. 10.

${ }^{22}$ Ibid p. 3, para. 3.

${ }^{23}$ Ibid p. 5, para. 13 .

${ }^{24}$ Ibid p. 6, para. 15 .

${ }^{25}$ Ibid.
} 
With regard to the shelling of Yeonpyeong Island by the DPRK on 23 November 2010, the shells fired hit both military and civilian objects on the island. ${ }^{26}$ The shelling resulted in the deaths of four people (two civilians and two military), injuries to sixty-six people (fifty civilians and sixteen military), and large-scale destruction of military and civilian facilities. ${ }^{27}$ The OTP considered that, on balance, the available information did not provide a reasonable basis to believe that the DPRK intentionally targeted the civilian population or civilian objects. ${ }^{28}$ Since the civilian population of the island was merely 1361, the OTP concluded that a reasonably well-informed person in the circumstances of the actual perpetrator would not have expected the civilian impact to be high. ${ }^{29}$ Thus, the situation of Republic of Korea was closed with a decision not to investigate unless further information later became available that would lead the Office to reconsider these conclusions in the light of new facts or evidence. ${ }^{30}$

\subsubsection{Situation of Ukraine and the Downing of MH17}

Although Ukraine belongs to the Eastern European region and is not an ICC State Party, its situation is under preliminary examination by the ICC and entails the downing of MH17, Malaysia Airlines flight 17, on 17 July 2014. While the state of registration of MH17 is an Asian regional state-Malaysia - she is also not an ICC State Party. The situation of the Ukraine is labelled a phase 2 situation, meaning that the preconditions to the exercise of jurisdiction and the existence of a reasonable basis to believe that the alleged crimes fall within the jurisdiction of the ICC are being considered. In terms of the jurisdictional basis for this non-State Party situation, it was not referred by the United Nations Security Council, but is based on a declaration by a non-State Party under Article 12(3) of the ICC Statute.

On 17 April 2014, the Government of Ukraine lodged a declaration under Article 12(3) of the Rome Statute and accepted the jurisdiction of the ICC over alleged crimes committed on its territory from 21 November 2013 to 22 February 2014. ${ }^{31}$ On 25 April 2014, the OTP opened a preliminary examination on the situation of Ukraine. ${ }^{32}$ On 8 September 2015, the government of Ukraine lodged a second declaration under Article 12(3), accepting the exercise of ICC jurisdiction in relation to alleged crimes committed on its territory from 20 February 2014 onwards, with no end date. ${ }^{33}$ Subsequently, the Prosecutor announced that the

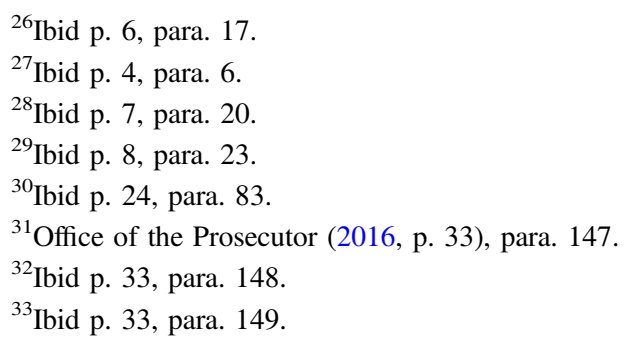


preliminary examination of the situation in Ukraine now includes alleged crimes occurring after 20 February 2014. ${ }^{34}$

The preliminary examination by the OTP considers that, in parallel with the existence of an international armed conflict between Ukraine and the Russian Federation beginning at the latest on 26 February 2014, there were intense anti-governmental protests in Eastern Ukrainian provinces. On 17 July 2014, a civilian Malaysia Airlines aircraft, flight MH17 from Amsterdam to Kuala Lumpur with 298 passengers and crewmembers, was shot down over Eastern Ukraine. It is alleged that some 80 of the passengers were children. ${ }^{35}$ There were no survivors, and the crewmembers were all citizens of Malaysia. The passengers on this aircraft were from the following countries: the Netherlands (193 victims), Malaysia (43 victims), Australia (27 victims), the Republic of Indonesia (12 victims), the United Kingdom (10 victims), Germany (4), Belgium (4 victims), the Republic of Philippines (3 victims), Canada ( 1 victim), and New Zealand (1 victim). ${ }^{36}$ An investigation was conducted by a joint investigation team comprising members from both some of the victims' states and the Ukraine and, according to this joint investigation, the aircraft was shot down from a location near Pervomaisk in territory controlled by anti-government armed groups. ${ }^{37}$ In Eastern Ukraine, fighting has persisted for more than two years between Ukrainian government forces and anti-government elements allegedly supported by the Russian Federation. ${ }^{38}$ The OTP has collected information about more than 800 incidents, including MH17, between February and November 2016 in the context of events in Eastern Ukraine, and the OTP continues to engage in a preliminary examination. ${ }^{39}$ In contrast to the Rome Statute, the Convention on Civil Aviation does not provide a legal framework for individual criminal responsibility. ${ }^{40}$ Since the shooting down of MH17 has been attributed to a likely non-state actor in the Ukraine, arguably with support from Russia, the states affected by the crash have allegedly tried to secure criminal accountability for the possible suspects rather than pursuing a compensation claim based on state responsibility. ${ }^{41}$

By adopting Resolution 2166 (2014) on 21 July 2014, the Security Council demanded that those responsible for shooting down MH17 be held to account and that all states cooperate fully with efforts to establish accountability. ${ }^{42}$ Since some states and civil society activists asked for an international ad hoc tribunal,

\footnotetext{
${ }^{34}$ Ibid.

${ }^{35}$ UN Doc. S/PV.7498 (29 July 2015), p. 6.

${ }^{36}$ The Dutch Safety Board, Preliminary Report: Crash Involving Malaysia Airlines Boeing 777200 Flight MH17, Hrabove, Ukraine, 17 July 2014 (September 2014) p. 12.

${ }^{37}$ Office of the Prosecutor (2016, p. 37), para. 165.

${ }^{38}$ Ibid p. 37, para. 166.

${ }^{39}$ Ibid p. 39, para. 177.

${ }^{40}$ Williams (2016, p. 211).

${ }^{41}$ Ibid.

${ }^{42}$ UN Doc. S/RES/2166 (21 July 2014), para. 11.
} 
a so-called MH17 tribunal, or the exercise of jurisdiction by the ICC, a draft resolution to establish such an ad hoc tribunal was presented by Malaysia before the Security Council on 29 July 2015, co-sponsored by Australia, Belgium, Canada, France, Germany, Ireland, Israel, Italy, Lithuania, the Netherlands, New Zealand, the Philippines, Romania, Spain, Ukraine, the United Kingdom, and the United States. ${ }^{43}$ However, Russia vetoed the draft resolution and prevented the establishment of an ad hoc tribunal. Angola, China, and Venezuela abstained from the resolution. $^{44}$

If the OTP should decide to open an investigation of incident, one question is the characterization of the shooting down of MH17. ${ }^{45}$ According to Professor Sarah Williams, the most likely characterization of the incident is as a potential war crime under Article 8 of the Rome Statute, because one of the requirements of this Article, namely the existence of an armed conflict, appears to be met by the non-international armed conflict between the armed forces of the government of the Ukraine and the separatists. ${ }^{46}$ Professor Williams said that, within the context of a non-international armed conflict, possible charges would be the war crime of murder as a violation of Common Article 3 of the Geneva Conventions of 1949 under Rome Statute Article 8(2)(c) and the war crime of intentionally directing attacks against the civilian population under Article 8(2)(e)(i). ${ }^{47}$ The most difficult element of war crimes to prove in this incident would be the contextual element of war crimes being "committed as part of a plan or policy or as part of a large-scale commission of such crimes" under Article 8(1). The shooting down of MH17 itself seems unlikely to fulfil this requirement. ${ }^{48}$

The mental elements of the separatists would also be difficult to prove unless the separatists targeted MH17 knowing it was a civilian aircraft and intending to destroy it. ${ }^{49}$ In addition, the involvement of Russia with the Ukrainian separatists appears not to have reached the level of overall control required to internationalize the conflict at the time of the shooting down of MH17 in July 2014. ${ }^{50}$

Last but not least, the ICC is only allowed to exercise jurisdiction when competent national courts are unwilling or unable to investigate and prosecute the most heinous crimes of interest to the international community. To meet this ICC admissibility test, the existence of a national investigation and prosecution of the same person and same conduct would be very important under the jurisprudence of

\footnotetext{
${ }^{43}$ UN Doc. S/2015/562 (29 July 2015), Annex, Statute of the International Criminal Tribunal for Malaysia Airlines Flight MH17.

${ }^{44}$ UN Doc. S/PV.7498 (29 July 2015), p. 2.

${ }^{45}$ Williams (2016, p. 216).

${ }^{46}$ Ibid.

${ }^{47}$ Ibid p. 217.

${ }^{48}$ Ibid p. 220.

${ }^{49}$ Ibid pp. $218-20$.

${ }^{50}$ Ibid p. 217.
} 
the ICC. ${ }^{51}$ At the same time, the crime would have to be of sufficient gravity in light of Article 17(1)(d) of the Rome Statute. In this respect, an international joint criminal investigation by Australia, Belgium, Malaysia, the Netherlands, and the Ukraine may be comprehensive and large-scale enough to cover similar investigative targets as the ICC OTP if were to select this incident for preliminary examination. ${ }^{52}$ Hence, the complementarity requirement of the Rome Statute does not yet seem to be met, especially considering paragraph 4 of Security Council resolution 2166 recognizing the efforts under way by the Ukraine to undertake an international investigation of the incident. ${ }^{53}$ For good or for bad, the MH17 incident seems unlikely to be investigated and prosecuted by the ICC, especially given that the ICC has a limited budget and resources targeting the perpetrators of the most serious crimes. Although some lawyers wish the OTP to investigate and prosecute the incident, ${ }^{54}$ the principle of complementarity - the principle of exhaustion of local remedies-remains a hurdle.

\subsubsection{Situation of Afghanistan}

Afghanistan became an ICC Member State in May 2003. Following 112 communications under Article 15 of the Rome Statute, a preliminary examination of the situation in Afghanistan was announced in 2007. ${ }^{55}$ The OTP considers the situation in Afghanistan to be an armed conflict of a non-international character between the Afghan government, supported by US forces and an international security force established by United Nations Security Council Resolution 1386, and non-state armed groups, particularly the Taliban. ${ }^{56}$ The OTP has already determined that a reasonable basis exists to believe that, at a minimum, the following crimes within the ambit of the Court's jurisdiction have occurred: (i) crimes against humanity and war crimes by the Taliban and its affiliated Haqqani Network; (ii) war crimes of torture and related ill-treatment by Afghan government forces, in particular the intelligence agency (National Directorate for Security) and the Afghan National Police; (iii) war crimes of torture and related ill-treatment by US military forces deployed to Afghanistan and in secret detention facilities operated by the Central

\footnotetext{
${ }^{51}$ Prosecutor v. Thomas Lubanga Dyilo, "Decision concerning Pre-Trial Chamber I's Decision of 10 February 2006 and the Incorporation of Documents into the Record of the Case against Mr. Thomas Lubanga Dyilo," Pre-Trial Chamber I, Case No. ICC-01/04-01/06 (24 February 2006) p. 20 para. 31. Nonetheless, the decision famously held that "the Chamber considers that it is $a$ conditio sine qua non for a case arising from the investigation of a situation to be inadmissible that national proceedings encompass both the person and the conduct which is the subject of the case before the court."

${ }^{52}$ Williams (2016, p. 222).

${ }^{53}$ UN Doc. S/RES/2166 (21 July 2014), para. 4.

${ }^{54}$ Reduan (2016).

${ }^{55}$ Office of the Prosecutor (2016, p. 43), para. 192.

${ }^{56}$ Ibid p. 44, para. 197.
} 
Intelligence Agency, principally in the 2003-2004 period. ${ }^{57}$ These crimes were seemingly committed in all 34 Afghanistan provinces ${ }^{58}$ and by three separate groups of perpetrators: members of the Taliban and their affiliates constituting anti-government groups, members of the Afghan authorities, and members of the US armed forces or the Central Intelligence Agency (CIA). ${ }^{59}$ The OTP has found the potential cases that would arise from an investigation of the situation of Afghanistan admissible pursuant to Article 53(1)(b), apparently fulfilling the requirements of Article $17 .{ }^{60}$

A few elements seem to remain uncertain for the OTP to open an investigation into the situation of Afghanistan officially. First, there exists a law on general amnesty passed by the Afghan parliament in $2007 .{ }^{61}$ The law entered into force in 2009, and it had neither a temporal limitation on its application nor an exception for international crimes. ${ }^{62}$ However, for now, the OTP "would have no substantial reasons to believe that the opening of an investigation would not be in the interests

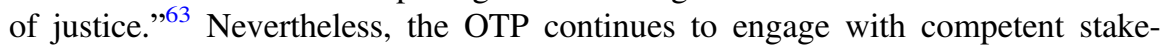
holders to assess whether there are substantial reasons to believe that an investigation would not serve the interests of justice before deciding whether to open an investigation into the situation. ${ }^{64}$ Whereas the complementarity test seems fulfilled for the crimes committed by members of anti-governmental groups and the Afghan authorities, the US Department of Justice conducted a preliminary review of allegations related to the abuse of the detainees in the custody of the Central Intelligence Agency, so the OTP is seeking to obtain further clarification on the scope of relevant preliminary reviews and investigations before finalising its determination on the admissibility of the US-related Afghan cases. ${ }^{65}$

The preliminary examination of the situation of Afghanistan has been already treated as a situation in phase 3 of admissibility. This implies that the preliminary examination has reached its final stage. The potential for opening an investigation may be dependent on the availability of domestic investigation and prosecution, as well as the outcome of those available justice alternatives, if any. The gravity of the crimes allegedly committed by the three separate groups of perpetrators in the territory of Afghanistan seems to be serious enough to satisfy the admissibility threshold under Article 53(1)(c) of the Rome Statute, for example the approximately 17,000 civilian casualties between January 2007 and June 2015 attributed to

\footnotetext{
${ }^{57}$ Ibid p. 44, para. 198.

${ }^{58}$ Ibid p. 44, para. 199.

${ }^{59}$ Ibid p. 47, para. 214.

${ }^{60}$ Ibid p. 47, para. 214.

${ }^{61}$ Ibid p. 48, para. 215.

${ }^{62}$ Ibid.

${ }^{63}$ Ibid p. 50, para. 225.

${ }^{64}$ Ibid p. 51, para. 228.

${ }^{65}$ Ibid pp. 48-49, paras. 221-222.
} 
anti-government armed groups. ${ }^{66}$ While the deterrent effect of opening of an OTP investigation on future crimes in Afghanistan remains questionable, the cycle of impunity should be halted, especially for those who are most responsible for the atrocities in Afghanistan.

\subsubsection{Situation of the Registered Vessels of Comoros, Greece and Cambodia}

Israel imposed a naval blockade on the Gaza Strip up to a distance of 20 nautical miles from the coast, ${ }^{67}$ on the high seas. After this blockade, the Free Gaza Movement was formed to challenge it. ${ }^{68}$ According to the OTP, the Free Gaza Movement consisted of an eight-vessel flotilla with over 700 passengers from approximately 40 countries seeking to (i) deliver aid to Gaza, (ii) break the Israeli blockade, and (iii) raise international awareness about the closure of the Gaza Strip and put pressure the international community to review its sanctions policy. ${ }^{69}$ Of the flotilla's eight ships, one was the Mavi Marmara, registered in the Comoros; the remaining ships were registered in Greece, Turkey, Kiribati, Cambodia, and the United States. ${ }^{70}$ Of these states of registration, the Comoros, Cambodia and Greece are ICC States Parties. The Cambodian-registered vessel was named the Rachel Corrie. ${ }^{71}$

On 31 May 2010, the Israeli Defence Forces (IDF) intercepted six vessels, including the Mavi Marmara. By that time, one of the eight vessels had withdrawn due to mechanical difficulties, and the Rachel Corrie was delayed in its departure. ${ }^{72}$ Although the captain of the Rachel Corrie informed Israel that he disputed the Israel's right to board, the Rachel Corrie offered no resistance and cut her engines, and the IDF soldiers boarded and detained the vessel peacefully. ${ }^{73}$ Therefore the OTP did not view the incident of the Rachel Corrie as an attack. ${ }^{74}$ However, the interception operation of the Mavi Marmara resulted in the death of ten passengers, nine of whom were Turkish nationals, and one had dual Turkish and American nationality. ${ }^{75}$ A United Nations Human Rights Council fact-finding mission was created to conduct an inquiry, and its report was delivered in September $2010 .^{76}$

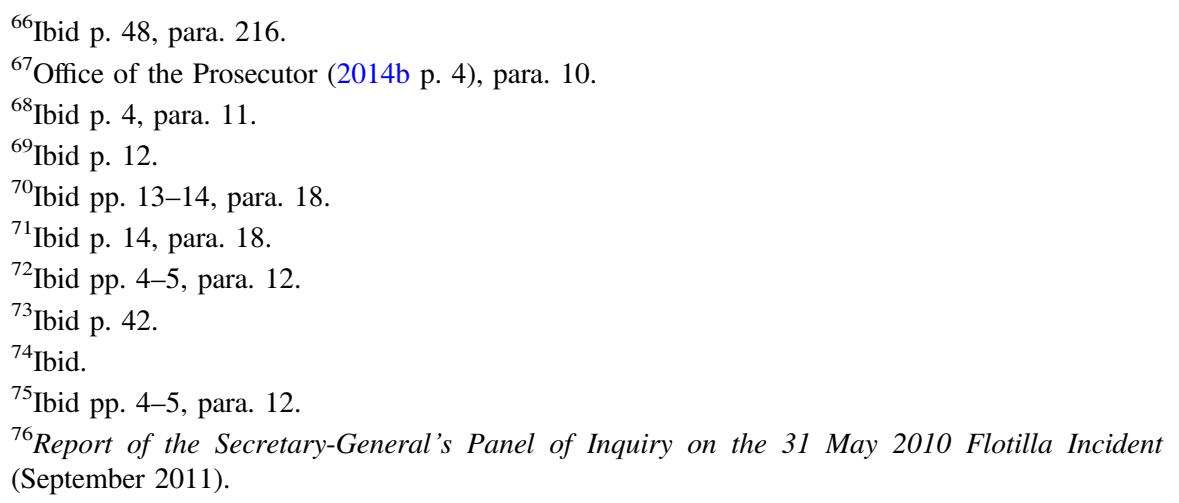


The OTP received a referral letter from the government of the Comoros, which had ratified the Rome Statute in $2006,{ }^{77}$ on 14 May $2013 .^{78}$ The Comoros asked the Prosecutor to look into the 31 May 2010 Israeli interception of the humanitarian aid flotilla bound for the Gaza Strip. ${ }^{79}$ On the same day as the referral, the prosecutor announced that she had opened a preliminary examination on it, but on 6 November 2014 she said that the information did not provide a reasonable basis to proceed with an investigation of the situation. Basically, the Prosecutor found that the gravity threshold for admissibility of the situation had not been satisfied for the incident of the Mavi Marmara.

The Mavi Marmara was carrying over 500 civilian passengers; nine of the 500 passengers were killed by the IDF during the interception, and another passenger later died of injuries caused by the 31 May 2010 incident. ${ }^{80}$ On the seven other vessels in the flotilla, no serious injuries occurred during the course of their interception. ${ }^{81}$ Therefore, the OTP found that the total number of victims of this situation was relatively limited compared with other cases investigated by the Office. ${ }^{82}$ According to the OTP, considering that Israel made offers and proposals to the flotilla participants to permit the delivery of humanitarian supplies through an alternative route and that the humanitarian supplies carried by the vessels were ultimately distributed in Gaza, the interception of the flotilla could not be considered to have a significant impact on the civil population of Gaza. ${ }^{83}$

However, on 29 January 2015, the Comoros filed an application for review of the Prosecutor's decision not to proceed. ${ }^{84}$ On 16 July 2015, Pre-Trial Chamber I requested the Prosecutor to reconsider her decision. ${ }^{85}$ On 6 November 2015, the Appeals Chamber dismissed the Prosecutor's appeal against the Pre-Trial Chamber's request. ${ }^{86}$ Rule 108, paragraph 2, of the ICC Rules of the Procedure and Evidence obligate the Prosecutor to reconsider a decision not to initiate an investigation "as soon as possible." Accordingly, the OTP considered the significance of information made available to the Prosecutor after her decision not to open an investigation. ${ }^{87}$ As of November 2016, the OTP is nearing the completion of its review of all information gathered and is preparing to issue the Prosecutor's final

\footnotetext{
${ }^{77}$ Union of the Comoros, Referral under Articles 14 and 12(2)(a) of the Rome Statute arising from the 31 May 2010, Gaza Freedom Flotilla Situation (14 May 2013).

${ }^{78}$ Union of the Comoros, Referral under Articles 14 and 12(2)(a) of the Rome Statute arising from the 31 May 2010, Gaza Freedom Flotilla Situation (14 May 2013).

${ }^{79}$ Office of the Prosecutor (2016, p. 69), para. 308.

${ }^{80}$ Office of the Prosecutor (2014b, p. 56).

${ }^{81}$ Ibid.

${ }^{82} \mathrm{Ibid}$.

${ }^{83}$ Ibid p. 57.

${ }^{84}$ Ibid p. 69 , para. 310 .

${ }^{85}$ Ibid p. 69 , para. 311.

${ }^{86}$ Ibid p. 69, para. 312.

${ }^{87}$ Ibid p. 73 , para. 330.
} 
decision under Rule 108, paragraph 3 , in the near future. ${ }^{88}$ In any event, as long as the interception of the Rachel Corrie is not characterized as an attack, and it did not involve any casualties, the preliminary examination of the registered vessels of Comoros, Greece, and Cambodia would not in the end have a direct relationship with the Asian region.

\subsection{Possible Targets in the Asian Region of the OTP's Preliminary Examination}

What are the future prospects for the Asian region and the ICC? There are some foggy prospects for both the ICC itself and its relationship with the Asian region. To be precise, the future prospects for the ICC and African countries are unclear and shaky compared with the ICC's relationship with Asian countries. Today, 34 states of 124 ICC Member States belong to the African continent. However, some African states, such as Burundi, South Africa, and Gambia were reported on October 2016 to be ready to exit from the ICC. ${ }^{89}$ Experts reportedly believe that Kenya, Namibia, and Uganda could be among the next countries leave the Court. ${ }^{90}$

The African States are still in flux. There is a glimmer of hope found the movements of some African countries. After the democratically elected President of Gambia, Mr. Adama Barrow, took his office in the end of January 2017, the Gambia notified the United Nations Secretary-General of the country's rescission of its withdrawal from the Rome Statute of the International Criminal Court. ${ }^{91}$ On 22 February 2017, the High Court of South Africa ordered that The notice of withdrawal from the Rome Statute of the International Criminal Court, signed by the Minister of International Relations and Cooperation on 19 October 2016, without prior parliamentary approval, is unconstitutional and invalid. Of course, it remains to be seen whether South Africa continues its membership of the ICC. ${ }^{92}$

On 13 October 2016, the Prosecutor expressed her concern about reported extra-judicial killings of alleged drug dealers and users in the Philippines. ${ }^{93}$ On 17 November 2016, the Philippines' president, Rodrigo Duterte, said that the

\footnotetext{
${ }^{88}$ Ibid p. 73 , para. 331.

${ }^{89}$ Sieff (2016).

${ }^{90}$ Ibid.

91،'Statement attributable to the Spokesman for the Secretary-General on the Occasion of the Gambia's Notification of Recession of its Withdrawal from the Rome Statute of the International Criminal Court" 16 February 2017, https://www.un.org/sg/en/content/sg/statement/2017-02-16/ statement-attributable-spokesman-secretary-general-occasion-gambia's (accessed 25 February 2017).

${ }^{92}$ Democratic Alliance v. Minister of International Relations and Cooperation and Others (Council for the Advancement of the South African Constitution Intervening), "Judgment", North Gauteng High Court, 83145/2016 [2017] ZAGPPHC 53 (22 February 2017).

${ }^{93}$ ICC-CPI (2016).
} 
Philippines might withdraw from the ICC, having heard the news from the OTP and the news of the Russian withdrawal of her signature from the Rome Statute. ${ }^{94}$ Just one day before the President Duterte's announcement, on 16 November 2016, the Russian President Vladimir Putin ordered his Foreign Ministry to inform the Secretary General of the United Nations that Russia had formally withdrawn her signature from the Rome Statute and no longer intended to participate in it. ${ }^{95}$ Yet, some hopeful signs may be found in the statement of the Philippines at the general debate of the 15th Assembly of States Parties on 17 November, the same day as the statement by the President Duterte on a possible withdrawal from the Rome Statute. The representative of the Philippines government confessed in closing his speech that "we await further instructions from the President of the Philippines, on the matter of our future relationship with the Court. Meanwhile, the Philippines fervently hopes for the faithful implementation of the system of the Rome Statute."96 Nonetheless, the government of the Philippines warned the OTP about the Prosecutor's statement on the situation in the Philippines, describing it as "premature." $" 97$ The report indirectly suggested the likelihood of a chilling effect on the interests of the Eastern Asian countries in joining the Rome Statute. ${ }^{98}$

Even though the potential harm from a few African states walking away from the Court and the Russian withdrawal of its signature from the Rome Statute are yet to be seen, the OTP must want to address the geographical imbalance among the situation countries of the Court so as to maintain its sociological legitimacy and substantive legitimacy for the Court's stakeholders, especially States Parties.

In addition to the current preliminary examination conducted by the OTP on incidents in the Asian region, massive human rights violations in Cambodia may be the next target for a preliminary examination by the OTP. On 7 October 2014, a communication under the Article 15 of the Rome Statute was filed with the OTP with regard to alleged crimes against humanity committed against Cambodian civilians through the Cambodian state apparatus. ${ }^{99}$ If the OTP takes this communication on Cambodian human rights violations seriously and the admissibility test

\footnotetext{
${ }^{94}$ Rauhala (2016).

${ }^{95}$ Plachta (2016, p. 463).

96“'Statement of the Philippines," General Debate of the 15th Assembly of States Parties to the Rome Statute of the International Criminal Court, World Forum, the Hague, Netherlands (17 November 2016) p. 2.

${ }^{97}$ Ibid.

${ }^{98}$ Ibid. The representative of the Philippines said that: "Without passing upon how that [the Prosecutor's] statement may have somehow chilled the interest of our neighboring countries in joining the Rome Statute, allow us to help clear the air."

${ }^{99}$ FIDH/Global Diligence, Executive Summary: Communication under Article 15 of the Rome Statute of the International Criminal Court: the Commission of Crimes against Humanity in Cambodia July 2002 to Present (7 October 2014) para. 1. See also FIDH Press Release, "Cambodia: Preliminary Examination Requested into Crimes Stemming from Mass Land Grabbing" (7 October 2014).
} 
is also met, then as one commentator has noted: "This shift is remarkable. Not only is the ICC beginning to move away from cases involving African States; it is also partly moving away from atrocities committed during war." ${ }^{100}$ Moreover, given the fact that the communication was driven by Cambodian victims' groups rather than a state's self-referral, as in many African situations, "[w]ere the Prosecutor's office to take on more files brought by victims or civil society, the ICC would appear to act on behalf of victims' rights rather than as a complaint tool of opportunistic political interests." 101

\section{Conclusion}

Active participation by Asian states in the ICC would be a step towards the Court's universality. The core values of the Rome Statute and the ICC are unambiguously linked to human dignity and the universality of human rights. The preamble of the Rome Statute stresses such universalism. For example, the first preambular paragraph says that State Parties to this Statute are conscious "that all people are united by common bonds, their cultures pieced together in a shared heritage, and concerned that this delicate mosaic may be shattered at any time." For the ICC to enhance its legitimacy among stakeholders, ensuring universality and the universal application of law is a key. Especially under the current circumstances of some African States stepping out of the ICC while accusing it of focusing on Africa, Asian regional support for the ICC would dispel growing distrust in the Court.

However, before doing that, the international community and State Parties, especially those of the Asian region, should give non-State Parties of the Asian region confidence about their domestic criminal justice systems in the context of the principle of complementarity of the Rome Statute. In this sense, the ICC is, inherently, not a charitable foundation through which developing countries and post-conflict countries can develop their domestic legal systems. The mandate of the ICC is restricted in this respect. Although the Trust Fund for Victims was established in accordance with Article 79 for the benefit of victims of crimes within the Court, there is no equivalent fund envisaged by the Statute to offer financial support for the establishment of independent and fair domestic legal systems.

Human rights are human's rights and shall be universal. Taking cynical attitudes towards the ICC under the cloak of the uniqueness of Asian culture runs counter to the basic spirit of human rights. As is well known, the Vienna Declaration and Programme of Action reiterates "the need to consider the possibility of establishing regional and subregional arrangements for the promotion and protection of human rights where they do not already exist." In this connection, the ASEAN Human Rights Declaration was adopted at the 21st the ASEAN summit in November 2012,

\footnotetext{
${ }^{100}$ Cruvellier (2016).

${ }^{101}$ Ibid.
} 
using the Vienna Declaration as a benchmark. ${ }^{102}$ Nonetheless, the Vienna Declaration may be interpreted as emphasising regionalism backed by universalism, as it declares:

While the significance of national and regional particularities and various historical, cultural and religious backgrounds must be borne in mind, it is the duty of States, regardless of their political, economic and cultural systems, to promote and protect all human rights and fundamental freedoms.

The Asian State Parties of the Rome Statute have already contributed to the development of the ICC in several ways. At the time of writing in January 2017, the Asian region holds three seats in the ICC judicial chambers: Republic of Korea Judge Chung-ho Chung, Japanese Judge Kuniko Ozaki, and Philippine Judge Raul Cano Pangalangan. These three Asian states' financial contribution to the ICC are also not small. ${ }^{103}$ In addition, the Asian region has already experienced the international prosecution of mass atrocities through the International Military Tribunal for the Far East (aka Tokyo tribunal), the Special Panels of the Dili District Court in East Timor, and the Extraordinary Chambers in the Courts of Cambodia. Against this background, the Asian region may contribute to the ICC by utilizing lessons from the past and taking the initiative in international criminal justice outreach. ${ }^{104}$

In 2017, the ICC will have the 15th anniversary of its creation. By its 20th anniversary, the Asian region or the ICC, which will be marginalised? The result remains to be seen, but the ratification map of the Rome Statute may already imply the marginalisation of the Asian region and the United States in international criminal justice. Scepticism and timid regionalism will not promote human rights, but undermine confidence in respecting universal human rights in the Asian region. Despite the Asian region's cultural uniqueness and various differences from Western cultures, the core values of international criminal justice are common through the world. The Asian region must also be a part of the fight against impunity and can enhance the legitimacy and universality of the International Criminal Court through the active participation of Asian states.

Acknowledgements This work was supported by JSPS KAKENHI Grant Number JP26780026. The author thanks for Professor Dr. Yumiko Nakanishi for her enthusiastic efforts to host the EUSI symposium in 30 January 2017.

\footnotetext{
${ }^{102}$ Jones (2014, pp. 77-78).

${ }^{103}$ For example, in 2016, Japan contributed to 23,391,916 euros, the Republic of Korea contributed 4,875,871 euros, and the Philippines contributed 385,802 euros. See Assembly of States Parties, Report of the Committee on Budget and Finance on the Work of Its Twenty-Seventh Session, ICC-ASP/15/15 (28 October 2016) pp. 36-67.

${ }^{104}$ Judge Song (2011, p. 8).
} 


\section{References}

Cruvellier T (2016) The ICC, out of Africa. The New York Times, 6 November

De Búrca G (2013) EU external relations: the governance mode of foreign policy. In: Van Vooren B, Blockmans S, Wouters J (eds) The EU's role in global governance: the legal dimension. Oxford University Press, Oxford, pp 39-58

Findlay M (2014) Sign up or sign off-Asia's reluctant engagement with the international criminal court. Cambodia Law Policy J 3:75-96

Forster K (2016) Philippines may withdraw from the international criminal court, says president Rodrigo Duterte: Vladimir Putin has signed an order to withdraw Russia's signature from the court's founding treaty. The Independent, 17 November

General Secretariat of the European Council (2009) The European Union and central Asia: the new partnership in action. DGF-Communication, Luxembourg

Groenleer M (2015) The United States, the European Union, and the international criminal court: similar values, different interests? Int J Const Law 13(4):923-944

Hafetz J (2014) China and the international criminal court. Chin (Taiwan) Y B Int Law Aff 32:3257

High Court of South Africa, North Gauteng High Court (2017) Judgment. Democratic Alliance v. Minister of International Relations and Cooperation and Others (Council for the Advancement of the South African Constitution Intervening) (83145/2016) [2017] ZAGPPHC 53

ICC-CPI (2016) Statement of the prosecutor of the international criminal court, Fatou Bensouda concerning the situation in the Republic of the Philippines. 13 October. https://www.icc-cpi. int//Pages/item.aspx?name=161013-otp-stat-php. Accessed 8 Jan 2016

Jianping L, Wang Z (2005) China's attitude towards the icc. JICJ 3(3):608-620

Jo H, Simmons BA (2016) Can the international criminal court deter atrocity? Int Organ 70 (3):443-475

Jones W (2014) Universalizing human rights the ASEAN way. Int J Soc Sci 3(3):72-89

Noguchi M (2006) Criminal justice in Asia and Japan and the international criminal court. Int Crim Law Rev 6(4):585-604

Office of the Prosecutor (2014a) Situation in the Republic of Korea: article 5

Office of the Prosecutor (2014b) Situation on registered vessels of Comoros, Greece and Cambodia: article 53(1) Report

Office of the Prosecutor (14 November 2016) Report on preliminary examination activities 2016

Plachta M (2016) Russia withdraws its signature from the statute of the international criminal court. Int Enforc Law Report 32(11):463

Rauhala E (2016) Taking a cue from Putin, Duterte may snub court. Washington Post Blogs. 18 November

Reduan H (2016) MH17: Malaysia could opt for international criminal court to seek justice. New Straits Times, 29 September

Sieff K (2016) Gambia Is the latest African country deciding to pull out of international criminal court; part of a wave of African antagonism toward the court, it is the third country to announce a pullout in 2 weeks. Washington Post Blogs 26 October

Song SH (2011) Role of Asian lawyers in emerging system of international criminal justice. In: Proceedings of the 24th annual conference of the Law Association for Asia and the Pacific (LAWASIA) Grand InterContinental Hotel, Seoul, 10 October 2011, 1-10

Toon V (2004) International criminal court: reservations of non-state parties in Southeast Asia. Contemp Southeast Asia 26(2):218-232

Williams S (2016) MH17 and the international criminal court: a suitable venue? Melb J Int Law 17 (1):210-237 


\section{Author Biography}

Hitomi Takemura an associate professor of international law, Hitotsubashi University, Japan. Her research focuses on the effectiveness, efficiency, and legitimacy of international criminal justice. She earned an LL.M. in international law from Hitotsubashi University, an LL.M. in public international law and international criminal law from Leiden University, and a Ph.D. in law from the Irish Centre for Human Rights at the National University of Ireland. She also worked as an intern at the Appeal Chamber of the International Criminal Tribunal for Rwanda and for the International Criminal Court. Her publications include e.g., International Human Right to Conscientious Objection to Military Service and Individual Duties to Disobey Manifestly Illegal Orders, Springer, 2008; Unmanned aerial vehicles: humanization from international humanitarian law, Wisconsin International Law Journal 2014; An analysis of legitimacy discourses in international criminal justice through comparative research on the ICC and the ECCC, Kokusaiho Gaiko Zasshi 2013; and Reconsidering the meaning and actuality of the legitimacy of the international criminal court, Amsterdam Law Forum 2012.

Open Access This chapter is licensed under the terms of the Creative Commons Attribution-NonCommercial-NoDerivatives 4.0 International License (http://creativecommons. org/licenses/by-nc-nd/4.0/), which permits any noncommercial use, sharing, distribution and reproduction in any medium or format, as long as you give appropriate credit to the original author (s) and the source, provide a link to the Creative Commons license and indicate if you modified the licensed material. You do not have permission under this license to share adapted material derived from this chapter or parts of it.

The images or other third party material in this chapter are included in the chapter's Creative Commons license, unless indicated otherwise in a credit line to the material. If material is not included in the chapter's Creative Commons license and your intended use is not permitted by statutory regulation or exceeds the permitted use, you will need to obtain permission directly from the copyright holder.

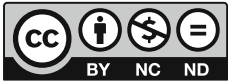

